Massimo Antonelli

Salvatore Maurizio Maggiore

\section{Consensus statement of the ESICM task force on colloid volume therapy in critically ill patients: editors' reply to Zacharowski et al.}

Accepted: 15 June 2012

Published online: 25 July 2012

(C) Copyright jointly held by Springer and ESICM 2012

M. Antonelli, Intensive Care Medicine, Editor in Chief.

S. M. Maggiore, Intensive Care Medicine, Deputy Editor and Chair of the Editorial and Publishing Committee of the ESICM.

Dear Dr. Zacharowski and

Colleagues,

Through the promotion of education, research and professional development, scientific societies have an extremely important role in the community of clinicians and scientists. A scientific society also has a political role in representing the particular concerns and interests of the medical community in its relationships with governmental entities. The European Society of Intensive Care Medicine (ESICM) accomplishes these tasks with special focus on the educational task. Several initiatives serve this purpose, including the production of recommendations and guidelines through the activity of task forces, working groups and the Systematic Review Group. The latter two are permanent entities. Task forces are temporary groups of experts with resources to accomplish a specific objective, namely the production of consensus-based recommendations on specific issues in collaboration with international associations.

Zacharowski et al. [1] commented on the recently published consensus statement of the ESICM Task Force on colloid volume therapy in critically ill patients [2]. Dr. Reinhart and colleagues [3] in their reply reported the criteria and process adopted for the composition of their task force, explaining that the selection criteria clearly take account of the 11 recommendations of the Guidelines International Network [4]. In agreement with this concept, task forces are validated by the ESICM, provided that the methodology is robust and conflicts of interest clearly disclosed.

Dr. Zacharowski and colleagues also expressed concern regarding the apparent shortness of the editorial process at Intensive Care Medicine, with the approval of the submitted article within $48 \mathrm{~h}$. This aspect needs clarification. The article produced by the task force coordinated by Dr. Reinhart, like any other article proposed to the ESICM for endorsement, was peer-reviewed by various independent referees before being approved. The article as published was revised and corrected by the authors following the suggestions of three reviewers, and only after that was it endorsed. The Editor-in-Chief of the journal and the Chair of the Editorial and Publishing Committee acted together, and the reviewers were chosen jointly. Only after having received endorsement by the ESICM was the article submitted officially to the journal. In such cases the editorial office may require additional revisions or accept as valid the comments of the reviewers chosen for the endorsement process. This is a summary of the process applied to the article before it was accepted apparently within 2 days.

\section{References}

1. Zacharowski K, Van Aken H, Marx G, Jacob M, Schaffartzik W, Zenz M, Loer SA, Ince C, Martin C, De Hert S, Hollmann MW, Girbes ARJ, KozekLangenecker S, Gombotz H, Guidet B, de la Rocca G, Wilson J, De Gasperi A (2012) Comments on Reinhart et al.: consensus statement of the ESICM task force on colloid volume therapy in critically ill patients. Intensive Care Med. doi:10.1007/s00134-012-2639-4

2. Reinhart K, Perner A, Sprung CL, Jaeschke R, Schortgen F, Johan Groeneveld AB, Beale R, Hartog CS (2012) Consensus statement of the ESICM task force on colloid volume therapy in critically ill patients. Intensive Care Med 38:368-383

3. Reinhart K, Perner A, Sprung CL, Jaeschke R, Schortgen F, Groeneveld ABJ, Beale R, Hartog CS (2012) Consensus statement of the ESICM task force on colloid volume therapy in critically ill patients: authors' reply to comments by Zacharowski et al. Intensive Care Med. doi: 10.1007/s00134-012-2641-x

4. Qaseem A, Forland F, Macbeth F, Ollenschlager $G$, Phillips $S$, van der Wees P (2012) Guidelines International Network: toward international standards for clinical practice guidelines. Ann Intern Med 156:525-531

M. Antonelli ( $\bullet$ ) S. M. Maggiore Department of Anesthesiology and Intensive Care, Policlicnico A. Gemelli University Hospital, Catholic University of Sacred Heart, Rome, Italy

e-mail:m.antonelli@rm.unicatt.it 